\title{
Review
}

\section{Peptidylarginine Deiminases as Mediators of Microvesicular Release - Novel Therapeutic Interventions}

\author{
Sigrun Lange ${ }^{1,2 *}$, Sharad Kholia ${ }^{3}$, Uchini S Kosgodage ${ }^{4}$, Mariya Hristova ${ }^{5}$, John Hardy ${ }^{6}$ and \\ Jameel M. Inal ${ }^{4}$ \\ 1 Department of Biomedical Sciences, University of Westminster, 115, New Cavendish Street, W1W 6UW, \\ UK; S.Lange@westminster.ac.uk \\ 2 University College London School of Pharmacy, 29-39 Brunswick Square, London WC1N 1AX, UK; \\ s.lange@ucl.ac.uk \\ 3 Department of Medical Sciences, Molecular Biotechnology Center, Corso Dogliotti 14, University of Turin, \\ Turin, Italy; sharad.kholia@gmail.com \\ 4 Cellular and Molecular Immunology Research Centre, School of Human Sciences, London Metropolitan \\ University, 166-220 Holloway Road, London, N7 8DB, UK; uck0002@my.londonmet.ac.uk \\ j.inal@londonmet.ac.uk \\ 5 Institute for Women's Health, University College London, 74 Huntley Street, London WC1N 6HX, UK; \\ m.hristova@ucl.ac.uk \\ 6 Reta Lila Weston Research Laboratories and Department of Molecular Neuroscience, UCL Institute of \\ Neurology, London, WC1N 3BG, UK; j.hardy@ucl.ac.uk \\ * Correspondence: S.Lange@westminster.ac.uk; Tel.: +44 (0)207 9115000 ext.64832
}

\begin{abstract}
Extracellular vesicle (EV) release, which occurs in most eukaryotic cells, has recently been associated with peptidylarginine deiminase (PAD)-driven protein deimination. Evidence points to the involvement of deiminated cytoskeletal proteins and changes in histone deimination. Both PADs and EVs are associated with various pathologies including cancers, autoimmune and neurodegenerative diseases. The elevated PAD expression observed in cancers may contribute to increase in EV shedding observed from cancer cells, contributing to cancer progression. Similarly, elevated PAD expression observed in neurodegenerative diseases may cause increased EV shedding and spread of neurodegenerative EV cargo, contributing to disease progression and pathologies. Pharmacological inhibition of PAD-mediated deimination using pan-PAD inhibitor $\mathrm{Cl}$-amidine, reduced cellular EV release in prostate cancer cells, rendering them significantly more susceptible to chemotherapeutic drugs. Studies on models of central nervous system damage have demonstrated critical functional roles for PADs and neuroprotective effects using PAD inhibitors in vivo, while human neurodegenerative iPSC in vitro models showed evidence of increased protein deimination. Besides using refined PAD inhibitors to selectively manipulate EV biogenesis for novel combination therapies in cancer treatment, we also speculate how EV biogenesis could be targeted via the newly identified PAD-pathway to ameliorate neurodegenerative disease progression.
\end{abstract}

Keywords: Extracellular vesicles (EVs); Peptidylarginine deiminases (PADs); Chlor-amidine (Cl$\mathrm{Am})$; cancer; neurodegeneration; deimination; cytoskeleton; induced pluripotent stem cells (iPSCs); histone $\mathrm{H} 3$; epigenetics.

\section{Introduction}

EVs are intact, submicron vesicles and include exosomes $(50-100 \mathrm{~nm}$ ) and microvesicles (MVs, 100-1000 $\mathrm{nm}$ in size), which are released from the cell membrane of diverse cell types upon stimulation and/or apoptosis [1,2]. EVs play physiological roles as mediators of intracellular communication, such as transferring growth factors, microRNAs and enzymes between cells, and play roles in diverse processes such as differentiation, migration and angiogenesis [3-7]. EV release 
depends on calcium ion influx, which occurs either through pores created by sublytic complement or stimulation of calcium channels such as P2X7 or calcium released by the endoplasmic reticulum through various calcium channels on activated cells [5]. This increase in cytosolic calcium results in cytoskeletal reorganisation, loss of membrane asymmetry, membrane blebbing and subsequent EV formation and release. The cytoskeletal rearrangement is known to be facilitated by the activation of various enzymes, including calpain, gelsolin, scramblase and protein kinase and the simultaneous inhibition of translocase and phosphatases [8]. In addition, recent discoveries on peptidylarginine deiminase (PAD)-mediated deimination of cytoskeletal proteins and histones have elucidated a novel crucial pathway in the facilitation of EV release [7]. As EVs are present in body fluids including blood, urine and cerebrospinal fluid, the identity of circulating EVs may serve as reliable biomarkers of pathophysiological processes $[1,2,8,9]$. EVs are emerging as novel therapeutic targets in treatment of disease as they have been shown to actively contribute to the progression of numerous pathologies including autoimmune diseases $[8,10]$, cancers $[7,11,12]$ and more recently neurodegenerative diseases [9,13-19]. Novel discoveries of mechanistic pathways involved, provide potential for the development of new diagnostic assays directed at identifying early stages of disease and response to therapy [1,2]. Peptidylarginine deiminases (PADs) are a family of tissue specific calcium activated enzymes that cause irreversible changes of protein-bound arginines into citrullines (Figure 1a) [20,21], resulting in protein misfolding and functional changes in target proteins (Figure 1b) [21-23]. Both cellular EV release and PAD-mediated protein deimination are calcium-dependent events that are elevated in a number of human diseases including cancer, autoimmunity and neurodegenerative diseases [10,24-31]. Addressing the putative interplay between PADs and EV biogenesis, we demonstrated in a recent prostate cancer study that PAD enzyme activation plays a functional role in EV biogenesis through deimination of cytoskeletal actins and nuclear histones [7]. The identification of this novel mechanistic pathway in EV biogenesis has revealed novel synergistic roles for PAD-mediated EV biogenesis in cancer progression.
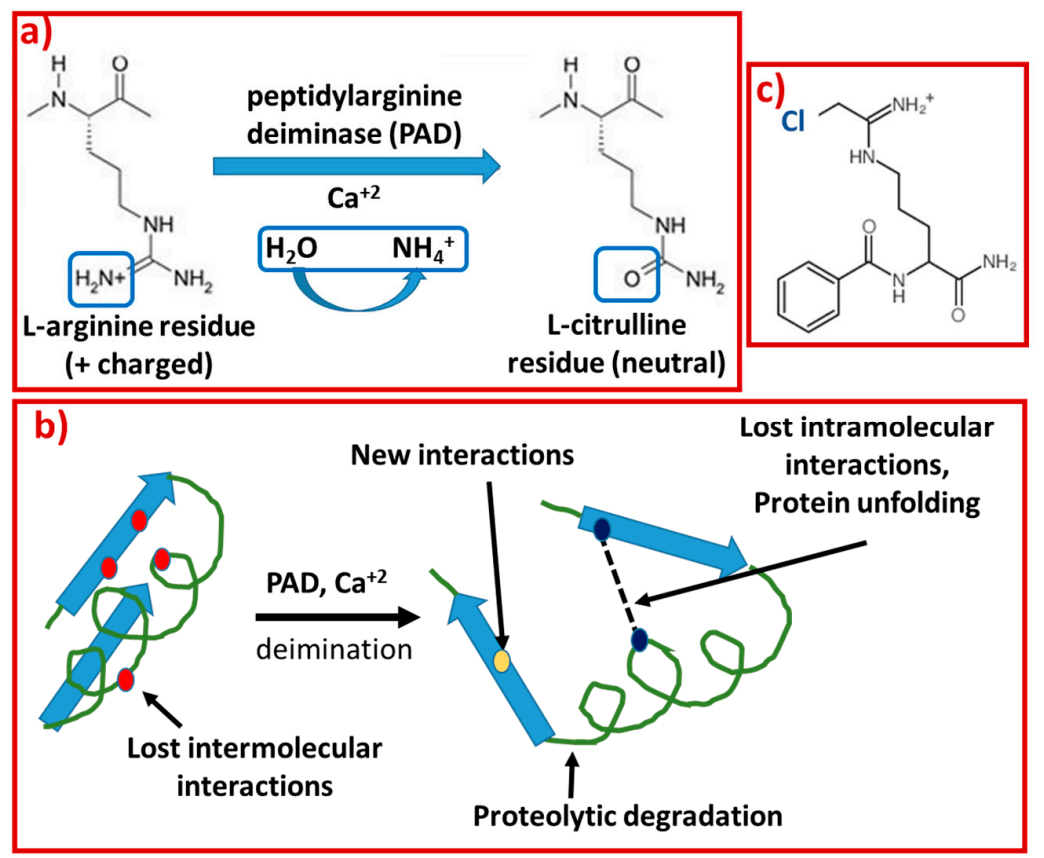

Figure 1. Post-translational protein deimination. a) Protein deimination is a post-translational modification mediated by peptidylarginine deiminases in a calcium catalysed manner. Positively charged arginine residues are modified into neutral citrulline, with ammonia as a by-product. This results in: b) change in protein charge (loss of one positive charge per conversion), lost intermolecular interactions, proteolytic degradation, change in protein conformation and unfolding and change or loss in function [21]. c) Cl-Amidine [141] is the most effective pan-PAD inhibitor used to date. 
As the use of the pan-PAD inhibitor Cl-Amidine (Figure 1c) significantly reduced EV biogenesis it is tempting to speculate how the manipulation of EVs via the PAD pathway may provide novel treatment options, not only for cancer progression, but also in other diseases associated with EVs, including neurodegenerative diseases. Previous studies on in vivo models of CNS damage showed that PAD-upregulation and increased protein deimination lead to vast neuronal death which was preventable by pharmacological PAD inhibition, significantly reducing neuroinflammatory responses and histone $\mathrm{H} 3$ deimination, which has implications in gene regulation [23,33-35]. In addition we have observed increased PAD expression during disease progression in tau mutation mouse models compared to age-matched controls [36]. Using iPSC neuronal models derived from fibroblasts from patients carrying neurodegenerative valosin containing protein VCPR155C and $V C P R 191 Q$ mutations [37,38], as well as from patients carrying $\alpha$-synuclein triplication [39] we have also observed significantly increased pan-protein deimination compared to control (non-mutation carrying) cultures, with significant changes in histone $\mathrm{H} 3$ deimination [36]. These studies are in accordance with the mounting evidence for significant roles for protein deimination in neurodegenerative diseases [40-45]. Roles identified for EVs in neurodegenerative disease progression so far include intercellular communication and neuroinflammation by transport of proteins, misfolded proteins, as well as mRNAs and miRNAs, which can be translated in recipient cells and affect gene regulation [46-48]. Unveiling the mechanisms of EV biogenesis and identifying pathways for modulation is thus pivotal for novel treatment options and interception in pathologies.

\section{EVs in Cancer}

Cumulative evidence implicates EVs in the pathogenesis of various diseases, including cancer, either directly or indirectly. Elevated EV levels in the blood from cancer patients compared to healthy individuals has been demonstrated by various investigators [49-51]. EV release has also been shown to aid tumour spread and survival as EVs transport various pathological growth factor receptors, soluble proteins and micro RNAs [5,6,8]. Interestingly, EV shedding from cancer cells also aids increased active drug efflux and thus contributes to their resistance to chemotherapeutic agents $[11,52]$. In addition, inhibition of microvesiculation has been shown to render cancer cells more susceptible to anticancer drug treatment $[7,11]$ and to reduce the dose of anti-cancer drug docetaxel required to limit tumor growth in vivo [53].

\section{PADs in Cancer}

In patients suffering from malignant tumours, the overexpression of the PAD2 and PAD4 isozymes has been reported in blood and tissues [54-56]. PAD4, which is commonly found in the nucleus [57,58], and the only isozyme that contains a classic nuclear localisation signal, has been shown to translocate to the nucleus in response to tumour necrosis factor alpha (TNF $\alpha$ ) upregulation [59]. PAD4 acts as a transcriptional co-regulator for various factors including p53, p300, p21 and ELK1 and via deimination of the N-terminal tails of various histone proteins [60-62]. PAD4 plays a role in apoptosis as it regulates p53 gene activity during DNA damage by acting as a co-mediator of gene transcription and epigenetic cross talk with histone deacetylase 2 (HDAC2) [63]. PAD4 is also colocalised with cytokeratin (CK), an established tumour marker which occurs in various isoforms, some of which are deiminated [64]. The deiminated CK isoforms become resistant to caspasemediated cleavage, contributing to the disruption of apoptosis in cancer tumours [64]. PAD4 also acts as a cofactor in epidermal growth factor-mediated target gene activity, activating the expression of proto-oncogene c-fos [62], interacting with p53 and influencing the expression of its target genes $[60,61,65,66]$. PAD4 is also linked with oestrogen receptor target gene activity via histone tail deimination [67]. In spite of lacking a classic nuclear translocation site such as found in PAD4, both PAD2 and PAD3 have also been localized and detected in the nucleus $[32,33,56,68]$. In cancer cells, PAD2, which is the most widely expressed isozyme in the body [20], has been shown to deiminate histone $\mathrm{H} 3$ and play a role in gene regulation $[30,56,69,70]$. 


\section{The interplay of EVs and PADs in Prostate Cancer}

We have recently shown novel roles for PADs in the biogenesis of EVs in prostate cancer and effective inhibition of EV biogenesis using pharmacological PAD-inhibition [7,71]. It was shown that PAD2 and 4 were present at significantly elevated levels in metastatic prostate PC3 cancer cells compared to a control benign (PNT2) prostate cell line [7]. Upon stimulating cells to microvesiculate, the nuclear translocation of PAD2 and particularly PAD4 was observed in the metastatic PC3 cancer cells, but prevented when the cells were pre-treated with PAD-inhibitor prior to stimulating the cells for EV release [7]. PAD4 has previously been shown to regulate histone arginine methylation levels in the nucleus [67]. It may be postulated that the PAD-mediated EV release cascade causing translocation of PADs to the nucleus also causes upregulation in TNF $\alpha$ as part of the inflammatory response, and as TNF $\alpha$ is implicated in nuclear translocation of PAD4 [59,72] this may cause in turn additional EV shedding. The pan-PAD inhibitor $\mathrm{Cl}-\mathrm{Am}$ had a dose-dependent inhibitory effect also on EV release in normal prostate control cell lines (PNT2) [7], indicating that PAD activity impacts cell communication via this pathway also in non-cancerous cells [7]. Which of the PAD isozymes is the main player in EV release is currently under investigation as the PADs may well be collectively involved with different, albeit equally important roles. Essentially, a novel mechanistic pathway for PADs in EV biogenesis via the deimination of cytoskeletal actin and histones, which can be selectively targeted using pharmacological PAD inhibition, has been identified in cancer [7].

\section{Deiminated Target Proteins Involved in EV Biogenesis}

The mechanism of EV release is regulated by either influx of $\mathrm{Ca}^{2+}$ that is released by the ER or through $\mathrm{Ca}^{2+}$ that enters the cell through pores generated by sublytic complement [8] or through the various calcium channels $[73,74]$ on activated cells. Besides leading to calpain-mediated cleavage of a variety of cytoskeletal actin filaments [75], $\mathrm{Ca}^{2+}$ influx also causes downstream PAD-activation, contributing to reorganisation of the cytoskeleton, thereby facilitating EV release [7]. Both $\beta$ - and Factin stress fibres play important roles in the redistribution of the actin-cytoskeleton during the EV formation process. This happens through the activation of Rho/Rho-associated kinase (ROCK) pathways during apoptosis and thrombin stimulation [76]. In PC3 cells the presence of deiminated $\beta$-actin increased in cells that were stimulated for EV release while pre-treatment with PAD-inhibitor markedly decreased $\beta$-actin deimination [7]. Beta actin, one of six different human actin isoforms, is a cytoskeletal protein involved in cell structure and integrity, cell migration and movement [77]. This provides evidence for the importance of PAD-mediated deimination of target proteins that are involved in cytoskeletal rearrangement, such as $\beta$-actin, actin alpha 1 and glyceraldehyde-3phosphate dehydrogenase, as an essential step for successful EV biogenesis. Upon PAD upregulation the deimination of cytoskeletal actin filaments facilitates the cytoskeletal reorganisation necessary for successful EV release while PAD inhibition prevents this deimination, rendering cytoskeleton less flexible and significantly impacts effective EV formation and shedding (Figure 2). Deiminated $\beta$ - and $\gamma$-actins have indeed also previously been detected in sera and synovial fluid from RA patients [78,79] and been identified as a substrate for PAD2 in ionomycin-activated neutrophils [80]. 


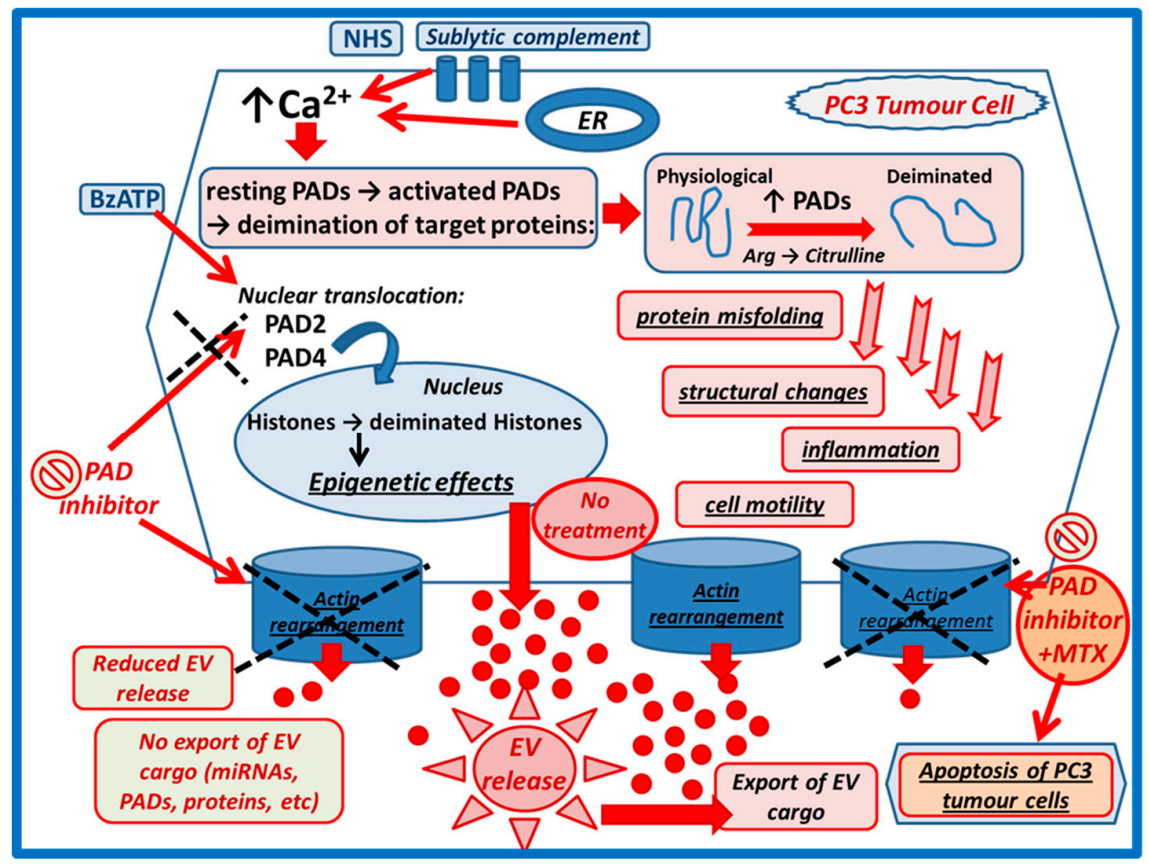

Figure 2. PADs in Extracellular vesicle biogenesis and the potential therapeutic application of PAD inhibitors in anti-cancer therapy. PAD2 and PAD4 are cytosolic enzymes, which during the course of cells being stimulated to microvesiculate (e.g. using BzATP stimulation of P2X7 channels or normal human serum (NHS) as a source of sublytic complement), by raised intracellular calcium levels, results in PAD enzymes (PAD2 and PAD4) translocating to the nucleus or remaining partially in the cytosol (PAD2). These PAD isozymes play a potential novel role in the biogenesis of EV release. This may happen by influencing actin-cytoskeleton cleavage and actin rearrangement and/or by nuclear histone deimination. The pharmacological inhibition of PADs abrogates the release of EVs, and when combined with the anticancer drug methotrexate (MTX), works synergistically to induce increased cytotoxic effects and apoptosis of PC3 tumour cells. [Based on 7]

\section{PAD Inhibitors in Synergy with Chemotherapeutic Drugs}

Cytotoxic effects of PAD inhibitors (Cl-Am and F-Am) have been shown on several cancer cell lines (HL60, MCF-7 and HT-29), while the viability of normal cells was not affected [31,81]. When using PAD inhibitors in synergy with chemotherapeutic agents such as for example doxorubicin, increased cancer cell cytotoxicity was observed [82]. In addition, PAD2 enzymatic activity has been shown to be inhibited by paclitaxel, which is used to treat neoplasms such as breast and ovarian cancers [83]. The novel pathway of PAD-mediated EV release in this context was first described in PC3 prostate cancer cells [7]. Depending on target protein preference of PAD2 and PAD4, EV release may occur via both cytoskeletal and epigenetic pathways. The different PAD isozymes have indeed demonstrated distinct substrate preferences, with PAD4 showing more restrictive substrate specificity compared to PAD2 [80,84-86]. While PAD4 prefers sequences with highly disordered conformation, PAD2 has a broader sequence specificity [87], which might partly be reflected by the broader tissue expression of PAD2 [20]. For example, PAD4 has been shown to be the main isozyme to deiminate histone $\mathrm{H} 3$, while PAD2 deiminates $\beta$ - and $\gamma$-actins [80]. The selectivity of PAD inhibitors and combinatory application with chemotherapeutic agents is thus of great interest. In PC3 cells, Cl-Am and Methotrexate (MTX) exerted synergistic cytotoxic effects on PC3 cells compared to MTX alone and significantly reduced EV biogenesis and release [7]. This radical reduction in EV shedding prevents the cancer cells from carrying out active drug efflux through EV shedding, and thus sensitizes them to chemotherapeutic drugs (Figure 2). Accordingly, other studies performed in our laboratories show that neoplastic cells are rendered more sensitive to cancer drugs when EV biogenesis is inhibited [11,71]. We have also shown that EV inhibition via a calpeptin inhibitor or 
siRNA limits tumour growth in vivo, emphasizing the important role of EV generation and manipulation for tumour growth [53].

\section{EVs and PADs in the Spread of Tumorigenesis}

EVs play various roles in cellular cross talk and act as carriers of active molecules that can have an effect at sites distal from the origin of EV release [1,2]. Both PAD2 and PAD4 isozymes are expressed in patients with malignant tumours and PAD expression is elevated in cancers, which in turn may cause increased EV release that contributes to cancer progression [7]. Intriguingly, the presence of PAD4 has been reported in the plasma of cancer patients without evidence for how it reaches that location [64]. Indeed, tumour cells may increase EV release in a PAD-dependent mechanism through which PAD enzymes are packaged in EVs and carried into plasma where they then deiminate target proteins (such as anti-thrombin) and aid in the spread of cancer indirectly. In the same vein, PAD enzymes may be packaged in EVs from non-cancerous cells in response to inflammation and elevated TNF $\alpha$ levels [7]. It can be postulated that EVs play similar roles in autoimmune and neurodegenerative diseases, explaining the unknown mechanism by which PAD molecules gain access to the extracellular space for example in rheumatoid arthritis (RA) where extracellular proteins such as collagen and fibrinogen are deiminated [88-90]. Another method by which PAD4 has been shown to be released from cells to generate deiminated antigens is neutrophil extracellular trap formation (NETosis) [91,92]. It may well be possible that PAD isozymes carried in EVs from different cells differ between physiological and disease states and vary between diseases. PADs exported in EVs in this manner may thus play previously unidentified and important roles in cancer, autoimmune and neurodegenerative diseases.

\section{PADs in Central Nervous System (CNS) damage and Neuroprotective Effects of PAD Inhibitors}

Previous work in two animal models of acute CNS damage has demonstrated that pharmacological pan-PAD inhibition is neuroprotective in vivo [32-34]. Administration of one dose of $\mathrm{Cl}-\mathrm{Am}(80 \mathrm{mg} / \mathrm{kg})$ straight after injury and up to two hours post-injury, in a chick-model of spinal cord damage, significantly reduced neuronal cell death, tissue loss and histone $\mathrm{H} 3$ deimination, compared to non-treated control injuries [32]. In two different mouse models of neonatal hypoxic ischaemic encephalopathy (HIE), firstly where permanent left carotid occlusion was followed with severe hypoxia (8\% oxygen for $60 \mathrm{~min}$ ), or secondly with 30 min hypoxia in combination with infection (as mimicked by LPS stimulation), one dose of Cl-Am (30 mg/kg) straight after hypoxia, or $10 \mathrm{~min}$ after LPS stimulation and again straight after hypoxia, significant reduction was observed in microglial activation, histone $\mathrm{H} 3$ deimination and cell death in all affected brain regions [33]. Interestingly, EV release has previously been associated with cerebral hypoxia induced by acute ischaemic stroke $[93,94]$ while increased protein deimination has also been detected in the pathology of traumatic brain injury [95]. The fact that dampening of neuroinflammation and neuroprotective effects are achieved in vivo, using pharmacological PAD inhibition, and that this effect is translatable between CNS injury and animal models, is indeed promising for effective application also in other cases of neuronal damage. The significance of PAD-mediated EV release and contribution of EV shedding in acute CNS damage is currently under investigation in our laboratories.

\section{EVs in Neurodegenerative Diseases}

EVs are increasingly being associated with neurodegenerative disease progression and pathologies [96-99]. In the CNS, EVs have been shown to be produced by several cell types including neurones, microglia, oligodendrocytes, astrocytes and embryonic neural stem cells [9] and play important roles in the development and function of the nervous system [100]. Roles for EVs in neurodegenerative disease progression include intercellular communication and neuroinflammation by transport of proteins, misfolded proteins, as well as mRNAs and miRNAs, which can be translated in recipient cells and affect gene regulation [46-48]. In Amyotrophic Lateral Sclerosis (ALS), EVs 
have for example been shown to export misfolded mutant SOD1 [101,102]; in relation to ALS and Frontotemporal dementia (FTD) to export TDP-43 [15,103]; and there is increasing evidence emerging for critical roles for miRNAs in the pathogenesis of FTD-ALS [104,105]. In tauopathies EVs have been shown to export phosphorylated tau [106,107]; in Parkinson's disease (PD) they export $\alpha$-synuclein and LRRK2, [19,108-110]; and in Alzheimer's disease (AD) they export A $\beta[111,112]$. All of these proteins form aggregates involved in the disease pathologies [113]. As EVs have the capability to travel further via the blood or cerebrospinal fluid, misfolded proteins may spread via this pathway in a prion-like manner [114-119]. In addition, functional effects of such protein transport has been indicated for $A \beta$, which progressively accumulates in EVs with age, while the $\beta$-site cleavage of APP has been reported to occur inside EVs [120]. Also, the phosphorylation of tau differs in exosomes compared to total cell lysates, indicating functional consequences for its seeding capability [106]. In AD neuroinflammation has been linked to circulating TNF $\alpha$ [121-123], which causes nuclear translocation of PADs [59,72], and to neutrophil extracellular trap formation [124], which is PAD4dependent [23,72]. In addition, in PD, $\alpha$-synuclein induces TNF- $\alpha$ containing exosomes from microglia [110] while TNF- $\alpha$ has been shown to promote EV shedding from endothelial cells [125]. In the light of this increasing evidence for crucial roles of EVs in neuroinflammation, and the transfer and spreading of neurodegenerative protein aggregates alongside other proteins, enzymes, mRNAs and miRNAs, the mechanisms of EV biogenesis and routes of modulation are pivotal.

\section{Protein Deimination in Neurodegenerative Diseases}

The evidence for critical roles of PADs in various neurodegenerative diseases is mounting [4045]. In many cases where protein deimination has been associated with neurodegenerative diseases, including multiple sclerosis (MS) [126-129], AD and PD, studies have mainly focused on histological analysis of post mortem human samples. AD post mortem human brain samples display increased protein deimination [41-43;130-132] and deiminated proteins are present in amyloid-containing areas in amyloid-precursor-protein / presenilin1 (APP+PSEN1) transgenic AD mouse models [31,133]. In AD patients, $\beta$-amyloid has been shown to be deiminated [31,43]. In hippocampal lysates from AD patients, glial fibrillary acidic protein (GFAP), an astrocyte-specific marker protein, and vimentin were identified as deiminated proteins and the deimination of GFAP was shown to be PAD2 specific [134]. In vitro studies demonstrated that amyloid peptides bind to PAD2, resulting in catalytic fibrillogenesis and formation of insoluble fibril aggregates [135]. In PD brain samples, increased levels of total protein deimination and deimination-positive extracellular plaques were observed [40]. Mutated $\alpha$-synuclein protein, resulting in misfolding, has been related to increased protein deimination [31]. Amyotrophic lateral sclerosis (ALS) spinal cords show increase in deiminated proteins [31] and Creutzfeldt Jacob Disease (CJD) brain samples indicate roles for deiminated enolase [136]. In AD brains, PTCD2 protein, an antigen target of an AD diagnostic autoantibody, is present in a deiminated form [137]. There are thus indications that disease-associated autoantibodies are generated due to the production and release of deiminated proteins and deiminated protein fragments, which may be released from damaged cells in regions of pathology [137,138]. In AD cortex and hippocampus, both PAD2 and PAD4 were shown to be expressed in cerebral cortex and hippocampus, the brain regions most vulnerable to AD pathology, with PAD2 localized in activated astrocytes and PAD4 selectively expressed in neurones. PAD4 expression was shown to co-localize with amyloid- $\beta-42$ in pyramidal neurones in cerebral cortex and in hippocampal large hilar neurones of the hippocampus, which were also surrounded by activated astrocytes and microglia [137]. These neurones contained cytoplasmic accumulations of deiminated proteins. Also, the release of deiminated proteins from necrotic neurones was thought to cause an increased exposure of deiminated neuronal proteins to the immune system. In addition, the continual return of cerebrospinal fluid to the circulation via the arachnoid villi, containing modified deiminated proteins and protein fragments, was suggested to be a key step in the ongoing pathology due to generation of autoantibodies [137].

PADs are thus expressed in neurones residing in brain regions that are engaged in neurodegenerative pathological changes and inflammatory changes such as reactive astrogliosis and 
microglial migration and invasion. Although some target proteins have been described, most deiminated proteins remain to be identified. We have, using proteomic analysis of deiminated proteins in the injured CNS [32,33,36], identified several proteins with neurodegenerative implications including neuroinflammation, perivascular drainage of $A \beta$, and the SNARE proteins, which are involved in EV release [139,140]. In pilot studies, using iPSC neuronal models derived from fibroblasts from patients [37] carrying valosin-protein containing mutations VCPR155C and VCPR191Q we have observed significantly increased pan-protein deimination compared to control (non-mutation carrying) neurones, with significant increases in histone H3 deimination in VCPR155C carrying neurones [36]. We also observed similar changes in pan-protein and histone $\mathrm{H} 3$ deimination in iPSC derived neurones from patients carrying $\alpha$-synuclein triplication [39] compared to control neurones [36]. The predominantly expressed isozyme observed was PAD4 while PAD2 was also expressed, albeit at lower levels [36]. Evidence for increased PAD expression with progression of neurodegenerative disease was obtained by analysis of whole genome microarrays from mouse models carrying TAU and APP+PSEN1 mutations. Significant increase of PADI2 transcription was found in cortex and hippocampus in both mutants with disease progression compared to age matched controls [36]. Figure 3 summarizes the proposed interplay of PADs and EVs in neurodegenerative disease pathologies. The contribution of PAD-mediated EV shedding in selected neurodegenerative mutations is currently under study using human iPSC models in our laboratories.

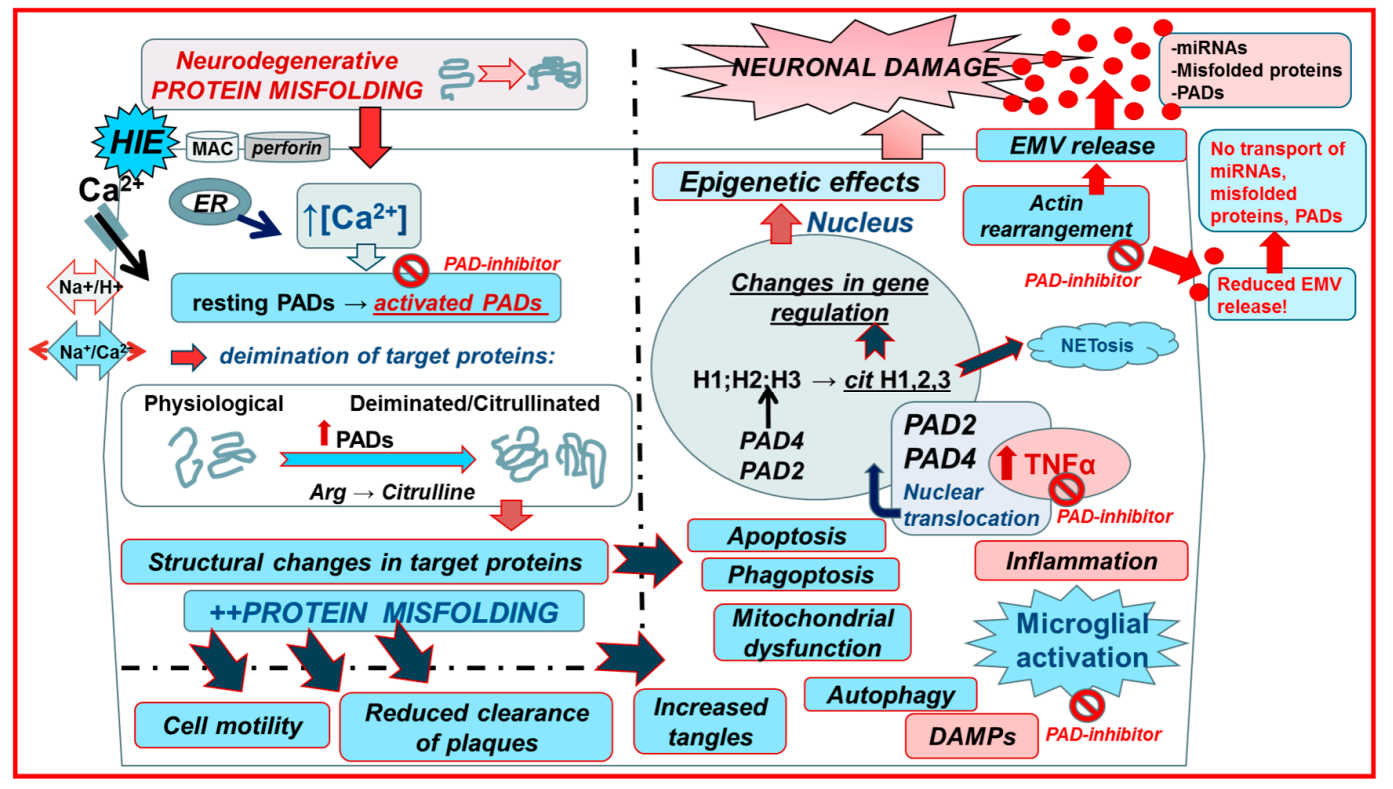

Figure 3. Mechanisms of PADs in CNS injury and Neurodegenerative Pathologies and the Use of PAD-inhibitors. Upon CNS injury (hypoxic ischaemic encephalopathy, HIE), $\mathrm{Ca}^{2+}$ entry is facilitated via the reversal of the $\mathrm{Na}^{+} / \mathrm{Ca}^{2+}$ exchanger due to over activation of the $\mathrm{Na}+\mathrm{H}+$ exchanger $(\mathrm{NHE}) . \mathrm{Ca}^{2+}$ entry can also be facilitated due to membranolytic pathways including the complement membrane attack complex (MAC) and perforin [based on 35 and 36]. Increased cytosolic $\mathrm{Ca}^{2+}$ triggers the neurotoxic cascade, which includes activation of the $\mathrm{Ca}^{2+}$ dependent PAD enzymes. Neurodegenerative disease mutations cause protein aggregation and impaired calcium buffering, which activates the downstream PAD-cascade. Both in CNS acute injury and neurodegeneration, PAD activation causes protein deimination and further protein misfolding, affecting cell motility, autophagy, phagoptosis, mictochondrial function, leading to neurotoxic events. Deiminated neoepitopes and leakage of deiminated proteins from dying cells contribute to neuroinflammation that in turn upregulates $\mathrm{TNF} \alpha$, which causes nuclear translocation of PADs, leading to histone deimination and formation of neutrophil extracellular traps (NETosis). PAD-mediated cytoskeletal protein deimination and histone deimination contribute to EV release, resulting in export of misfolded proteins, miRNAs, enzymes (including PADs) and other EV cargo that can contribute to pathologies. PAD-inhibitior $\mathrm{Cl}$-Amidine targets $\mathrm{PAD}$ activation and reduces deimination of target 
proteins and neuroinflammatory responses [32,33,36]. Cl-Amidine also significantly reduces EV shedding via histone deimination and by affecting cytoskeletal rearrangement [7], resulting in decreased transport of noxious EV cargo.

\section{Conclusions}

Recent studies have shown novel roles for PAD2 and PAD4 in the biogenesis of cellular microvesiculation [7]. EV release can be modulated using pharmacological PAD inhibitors to render metastatic prostate PC3 cancer more susceptible to chemotherapeutic drugs. PADs may affect EV biogenesis directly through deimination of cellular actins and other cytoskeletal components, facilitating cytoskeletal rearrangement for effective EV biogenesis, or indirectly through histone deimination via nuclear PAD translocation. Increased EV shedding from cancer cells, facilitated in part by upregulated PAD expression, also acts as a protective mechanism of cancer cells to expel chemotherapeutic drugs. Functional roles for PADs in CNS damage, and neuroprotective pharmacological intervention in vivo, have recently been established and provide evidence for crucial roles of PAD-mediated mechanisms in neuroinflammation [32-35]. Pilot studies using human iPSC neuronal models, derived from patients' fibroblasts carrying neurodegenerative disease mutations, show increased PAD activity and PAD-mediated deimination that will also affect downstream EV release [36]. These neurodegenerative iPSC models will be useful functional tools for continuing studies on effects of PAD-mediated EV shedding, and the efficacy of pharmacological modulation of PAD-mediated mechanisms to ameliorate neurodegenerative disease pathologies. While Cl-Am [141] remains the most used experimental inhibitor to date, the therapeutic potential and generation of second generation and selective isozyme-specific PAD inhibitors is receiving ever increasing attention [72,82,142-146]. Ongoing work aims at dissecting the roles of individual PAD isozymes in EV biogenesis, to identify further deiminated key target proteins, assess the epigenetic impact of histone deimination, and to evaluate disease-specific EV cargo. The use of targeted isozyme-selective PAD inhibitors to modulate EV release pose as promising combinatory therapies for various pathologies including cancers, autoimmune and neurodegenerative diseases.

\section{Abbreviations}

$\begin{array}{ll}\text { AD } & \text { Alzheimer's disease } \\ \text { ALS } & \text { Amyotrophic lateral sclerosis } \\ \text { APP } & \text { Amyloid precursor protein } \\ \text { CJD } & \text { Creutzfeldt Jacob Disease } \\ \text { CK } & \text { Cytokeratin } \\ \text { Cl-Am } & \text { Chlor-amidine } \\ \text { CNS } & \text { Central nervous system } \\ \text { EV } & \text { Extracellular vesicle } \\ \text { FTD } & \text { Frontotemporal dementia } \\ \text { GFAP } & \text { Glial fibrillary acidic protein } \\ \text { HDAC2 } & \text { Histone deacetylase 2 } \\ \text { HIE } & \text { Hypoxic ischaemic encephalopathy } \\ \text { iPSC } & \text { Induced pluripotent stem cell } \\ \text { LPS } & \text { Lipopolysaccharide } \\ \text { LRRK2 } & \text { Leucine-rich repeat kinase 2 } \\ \text { MAC } & \text { Membrane attack complex } \\ \text { MS } & \text { Multiple sclerosis } \\ \text { MV } & \text { Microvesicle } \\ \text { NET } & \text { Neutrophil extracellular trap } \\ \text { PAD } & \text { Peptidylarginine deiminase } \\ \text { PC3 } & \text { Prostate cancer cell line } \\ \text { PD } & \text { Parkinson disease } \\ \text { PNT2 } & \text { Control benign prostate cell line } \\ \text { PSEN1 } & \text { Presenilin 1 } \\ & \end{array}$


10 of 17

$\begin{array}{ll}\text { RA } & \text { Rheumatoid arthritis } \\ \text { ROCK } & \text { Rho/Rho-associated kinase } \\ \text { SNARE } & \text { SNAP (Soluble NSF Attachment Protein) REceptor } \\ \text { SOD1 } & \text { Superoxide dismutase 1 } \\ \text { TDP-43 } & \text { TAR DNA-binding protein } 43 \\ \text { TNF } \alpha & \text { Tumour necrosis factor alpha } \\ \text { VCP } & \text { Valosin containing protein }\end{array}$

\section{References}

1. Piccin, A.; Murphy, W.G.; Smith, O.P. Circulating microparticles: pathophysiology and clinical implications. Blood Rev 2007, 21, 157-71.

2. Inal, J.M.; Kosgodage, U.; Azam, S.; Stratton, D.; Antwi-Baffour, S.; Lange, S. Blood/plasma secretome and microvesicles. Biochim Biophys Acta 2013, 1834, 2317-25.

3. Ansa-Addo, E.A.; Lange, S.; Stratton, D.; Antwi-Baffour, S.; Cestari, I.; Ramirez, M,I.; McCrossan, M.V.; Inal, J.M. Human plasma membrane-derived vesicles halt proliferation and induce differentiation of THP1 acute monocytic leukemia cells. J Immunol 2010, 185, 5236-46.

4. Muralidharan-Chari, V.; Clancy, J.W.; Sedgwick, A.; D'Souza-Schorey, C. Microvesicles: mediators of extracellular communication during cancer progression. J Cell Sci 2010, 12, 1603-11.

5. Turola, E.; Furlan, R.; Bianco, F.; Matteoli, M.; Verderio, C. Microglial microvesicle secretion and intercellular signaling. Front Physiol, 2012, 22, 3, 149.

6. Kholia, S.; Ranghino, A.; Garnieri, P.; Lopatina, T.; Deregibus, M.C.; Rispoli, P.; Brizzi, M.F.; Camussi, G. Extracellular vesicles as new players in angiogenesis. Vascul Pharmacol 2016, 86, 64-70.

7. Kholia, S.; Jorfi, S.; Thompson, P.R.; Causey C.P.; Nicholas A.P.; Inal J.M.; Lange, S. A novel role for peptidylarginine deiminases in microvesicle release reveals therapeutic potential of PAD inhibition in sensitizing prostate cancer cells to chemotherapy. J Extracell Vesicles 2015, 4, 26192.

8. Inal, J.M.; Ansa-Addo, E.A.; Stratton, D.; Kholia, S.; Antwi-Baffour, S.S.; Jorfi, S.; Lange, S. Microvesicles in health and disease. Arch Immunol Ther Exp (Warsz) 2012, 60(2), 107-21.

9. Porro, C.; Trotta, T.; Panaro, M.A. Microvesicles in the brain: Biomarker, messenger or mediator? J Neuroimmunol 2015, 288, 70-78.

10. Antwi-Baffour, S.; Kholia, S.; Aryee, Y.K.; Ansa-Addo, E.A.; Stratton, D.; Lange, S.; Inal, J.M. Human plasma membrane-derived vesicles inhibit the phagocytosis of apoptotic cells - possible role in SLE. Biochem Biophys Res Commun 2010, 398, 278-83.

11. Jorfi, S.; Inal, J.M. The role of microvesicles in cancer progression and drug resistance. Biochem Soc Trans 2013, 41, 293-8.

12. Stratton, D.; Moore, C.; Antwi-Baffour, S.; Lange, S.; Inal, J. Microvesicles released constitutively from prostate cancer cells differ biochemically and functionally to stimulated microvesicles released through sublytic C5b-9. Biochem Biophys Res Commun 2015, 460(3), 589-95.

13. Brites, D.; Vaz, A.R. Microglia centered pathogenesis in ALS: insights in cell interconnectivity. Front Cell Neurosci 2014, 8, 117.

14. Gupta, A.; Pulliam, L. Exosomes as mediators of neuroinflammation. J Neuroinflammation 2014, 11, 68.

15. Nonaka, T.; Masuda-Suzukake, M.; Arai, T.; Hasegawa, Y.; Akatsu, H.; Obi, T.; Yoshida, M.; Murayama, S.; Mann, DM.; Akiyama, H.; Hasegawa, M. Prion-like properties of pathological TDP-43 aggregates from diseased brains. Cell Rep 2013, 4 pp. 124-134.

16. Basso, M.; Bonetto, V. Extracellular Vesicles and a Novel Form of Communication in the Brain. Front Neurosci 2016, 10, 127.

17. Colombo, E.; Borgiani, B.; Verderio, C.; Furlan, R. Microvesicles: novel biomarkers for neurological disorders. Front Physiol 2012, 29 (3), 63.

18. Wren, M.C.; Zhao, J.; Liu, C.C.; Murray, M.E.; Atagi, Y.; Davis, M.D.; Fu, Y.; Okano, H.J.; Ogaki, K.; Strongosky, A.J.; Tacik, P.; Rademakers, R.; Ross, O.A.; Dickson, D.W.; Wszolek, Z.K.; Kanekiyo, T.; Bu, G. Frontotemporal dementia-associated $\mathrm{N} 279 \mathrm{~K}$ tau mutant disrupts subcellular vesicle trafficking and induces cellular stress in iPSC-derived neural stem cells. Mol Neurodegener 2015, 15(10), 46.

19. Schindler, S.M.; Little, J.P.; Klegeris, A. Microparticles: a new perspective in central nervous system disorders. Biomed Res Int 2014, 756327. 
20. Watanabe, K.; Akiyama, K.; Hikichi, K.; Ohtsuka, R.; Okuyama, A.; Senshu, T. Combined biochemical and immunochemical comparison of peptidylarginine deiminases present in various tissues. Biochim Biophys Acta 1988, 966, 375-83.

21. Vossenaar, E.R.; Zendman, A.J.; van Venrooij, WJ, Pruijn, GJ. PAD, a growing family of citrullinating enzymes: genes, features and involvement in disease. Bioessays 2003, 25, 1106-18.

22. Gyorgy, B.; Toth, E.; Tarcsa, E.; Falus, A.; Buzas, E.I. Citrullination: a posttranslational modification in health and disease. Int J Biochem Cell Biol 2006, 38(10), 1662-77.

23. Wang, Y.; Li, M.; Stadler, S.; Correll, S.; Li, P.; Wang, D.; Hayama, R.; Leonelli, L.; Han, H.; Grigoryev, S.A.; Allis, C.D.; Coonrod, S.A. Histone hypercitrullination mediates chromatin decondensation and neutrophil extracellular trap formation. Cell Biol 2009, 184(2), 205-13.

24. Berckmans, R.J.; Nieuwland, R.; Kraan, M.C.; Schaap, M.C.; Pots, D.; Smeets, T.J.; Sturk, A.; Tak, P.P. Synovial microparticles from arthritic patients modulate chemokine and cytokine release by synoviocytes. Arthritis Res Ther 2005, 7, R536-44.

25. Migliorini, P.; Pratesi, F.; Tommasi, C.; Anzilotti, C. The immune response to citrullinated antigens in autoimmune diseases. Autoimmun Rev 2005, 4, 561-4.

26. Nomura, S.; Ozaki, Y.; Ikeda, Y. Function and role of microparticles in various clinical settings. Thromb Res 2008, 123, 8-23.

27. Anzilotti, C.; Pratesi, F.; Tommasi, C.; Migliorini, P. Peptidylarginine deiminase 4 and citrullination in health and disease. Autoimmun Rev 2010, 9, 158-60.

28. Castellana, D.; Toti, F.; Freyssinet, J.M. Membrane microvesicles: macromessengers in cancer disease and progression. Thromb Res 2010, 125:S84-8.

29. Mohanan, S.; Cherrington, B.D.; Horibata, S.; McElwee, J.L.; Thompson, P.R.; Coonrod, S.A. Potential role of peptidylarginine deiminase enzymes and protein citrullination in cancer pathogenesis. Biochem Res Int 2012, 895343.

30. McElwee, J.L.; Mohanan, S.; Griffith, O.L.; Breuer, H.C.; Anguish, L.J.; Cherrington, B.D.; Palmer, A.M.; Howe, L.R.; Subramanian, V.; Causey, C.P.; Thompson, P.R.; Gray, J.W.; Coonrod, S.A. Identification of PADI2 as a potential breast cancer biomarker and therapeutic target. BMC Cancer 2012, 12, 500.

31. Nicholas, A.P.; Lu, L.; Heaven, M.; Kadish, I.; van Groen, T.; Accaviti-Loper, M.A.; Wewering, S., Kofskey, D., Gambetti, P.; Brenner, M. Ongoing studies of deimination in neurodegenerative diseases using the F95 antibody. In: Nicholas, A.P.; Bhattacharya, S.K., Eds. Protein deimination in human health and disease. New York, NY: Springer Science and Business Media 2014, pp. 257-80.

32. Lange S.; Gögel S.; Leung K.Y.; Vernay B.; Nicholas, A.P.; Causey, C.P.; Thompson, P.R.; Greene, N.D.; Ferretti, P. Protein deiminases: new players in the developmentally regulated loss of neural regenerative ability. Dev Biol 2011, 355, 205-14.

33. Lange, S.; Rocha-Ferreira, E.; Thei, L.; Mawjee, P.; Bennett, K.; Thompson, P.R.; Subramanian, V.; Nicholas, A.P.; Peebles, D.; Hristova, M.; Raivich, G. Peptidylarginine deiminases: novel drug targets for prevention of neuronal damage following hypoxic ischemic insult (HI) in neonates. J Neurochem 2014, 130, 555-62.

34. Ferretti, P.; Lange, S.; U, P.K.; Raivich, G. "Deimination in the developing CNS - role in its response to traumatic and hypoxic injury". In: Nicholas, A.P.; Bhattacharya, S.K., Eds. Protein deimination in human health and disease. New York, NY: Springer Science and Business Media 2014, Chapter 15.

35. Lange, S. Peptidylarginine Deiminases as Drug Targets in Neonatal Hypoxic-Ischemic Encephalopathy. Front Neurol 2016, 7, 22.

36. Lange, S.; Wray, S.; Devine, M.; Matarin, M.; Hardy, J. Protein Deimination in Protein Misfolding Disorders - Modelled in Human Induced Pluripotent Stem Cells (iPSCs). In: Nicholas, A.P.; Bhattacharya, S.K., Eds. Protein deimination in human health and disease. Volume 2. New York, NY: Springer Science and Business Media, Chapter 24. Springer - in press.

37. Wray, S.; Self, M.; NINDS Parkinson's Disease iPSC Consortium; NINDS Huntington's Disease iPSC Consortium; NINDS ALS iPSC Consortium; Lewis, P.A.; Taanman, J.W.; Ryan, N.S.; Mahoney, C.J.; Liang, Y.; Devine, M.J.; Sheerin, U.M.; Houlden, H.; Morris, H.R.; Healy, D.; Marti-Masso, J.F.; Preza, E.; Barker, S.; Sutherland, M.; Corriveau, R.A.; D'Andrea, M.; Schapira, A.H.; Uitti, R.J.; Guttman, M.; Opala, G.; Jasinska-Myga, B.; Puschmann, A.; Nilsson, C.; Espay, A.J.; Slawek, J.; Gutmann, L.; Boeve, B.F.; Boylan, K.; Stoessl, A.J.; Ross, O.A.; Maragakis, N.J.; Van Gerpen, J.; Gerstenhaber, M.; Gwinn, K.; Dawson, T.M.; Isacson, O.; Marder, K.S.; Clark, L.N.; Przedborski, S.E.; Finkbeiner, S.; Rothstein, J.D.; Wszolek, Z.K.; 
Rossor, M.N.; Hardy, J. Creation of an open-access, mutation-defined fibroblast resource for neurological disease research PLoS One 2012, 7(8), e43099.

38. Bartolome, F.; Wu, H.C.; Burchell, V.S.; Preza, E.; Wray, S.; Mahoney, C.J.; Fox, N.C.; Calvo, A.; Canosa, A.; Moglia, C.; Mandrioli, J.; Chiò, A.; Orrell, R.W.; Houlden, H.; Hardy, J.; Abramov, A.Y.; Plun-Favreau, H. Pathogenic VCP mutations induce mitochondrial uncoupling and reduced ATP levels. Neuron 2013, 78(1), 57-64.

39. Devine, M.J.; Ryten, M.; Vodicka, P.; Thomson, A.J.; Burdon, T.; Houlden,H.; Cavaleri, F.; Nagano, M.; Drummond, N.J.; Taanman, J.W.; Schapira, A.H.; Gwinn, K.; Hardy, J.; Lewis, P.A.; Kunath T. Parkinson's disease induced pluripotent stem cells with triplication of the $\alpha$-synuclein locus. Nat Commun 2011, 2, 440.

40. Nicholas, A.P. Dual immunofluorescence study of citrullinated proteins in Parkinson diseased substantia nigra. Neurosci Lett 2011, 495, 26-29.

41. Ishigami, A.; Ohsawa, T.; Hiratsuka, M.; Taguchi, H.; Kobayashi, S.; Saito, Y.; Murayama, S.; Asaga, H.; Toda, T.; Kimura, N.; Maruyama, N. Abnormal accumulation of citrullinated proteins catalyzed by peptidylarginine deiminase in hippocampal extracts from patients with Alzheimer's disease. J Neurosci Res 2005, 80(1), 120-128.

42. Ishigami, A.; Choi, E-K.; Kim,S.; Maruyama, N. Deimination in Alzheimer's Disease. In: Nicholas, A.P.; Bhattacharya, S.K., Eds. Protein deimination in human health and disease. New York, NY: Springer Science and Business Media 2014, Chapter 13.

43. Nicholas, A.P. Dual immunofluorescence study of citrullinated proteins in Alzheimer diseased frontal cortex. Neurosci Lett 2013, 545, 107-11.

44. Jang, B.; Jin, J.K.; Jeon, Y.C.; Cho, H.J.; Ishigami, A.; Choi, K.C.; Carp, R.I.; Maruyama, N.; Kim, Y.S.; Choi, E.K. Involvement of peptidylarginine deiminase-mediated post-translational citrullination in pathogenesis of sporadic Creutzfeldt-Jakob disease. Acta Neuropath 2009, 119(2), 199-210.

45. Yang, L.; Tan, D.; Piao, H. Myelin Basic Protein Citrullination in Multiple Sclerosis: A Potential Therapeutic Target for the Pathology. Neurochem Res 2016, 41(8), 1845-56.

46. Valadi, H.; Ekstrom, K.; Bossios, A.; Sjostrand, M.; Lee, J.J.; Lotvall, J.O. Exosomemediated transfer of mRNAs and microRNAs is a novel mechanism of genetic exchange between cells. Nat Cell Biol 2007, 9(6):654-9.

47. Pegtel, D.M.; Peferoen, L.; Amor, S. Extracellular vesicles as modulators of cell-to-cell communication in the healthy and diseased brain. Philos Trans R Soc Lond B Biol Sci 2014, 369, 1652.

48. Coleman, B.M.; Hill, A.F. Extracellular vesicles -Their role in the packaging and spread of misfolded proteins associated with neurodegenerative diseases. Semin Cell Dev Biol 2015, 40, 89-96.

49. Ginestra, A.; La, P.; Saladino, F.; Cassarà, D.; Nagase, H.; Vittorelli, M.L. The amount and proteolytic content of vesicles shed by human cancer cell lines correlates with their in vitro invasiveness. Anticancer Res 1998, 18, 3433-7.

50. Kim, H.K.; Song, K.S.; Park, Y.S.; Kang, Y.H.; Lee, Y.J.; Lee, K.R.; Kim, H.K.; Ryu, K.W.; Bae, J.M.; Kim, S. Elevated levels of circulating platelet microparticles, VEGF, IL-6 and RANTES in patients with gastric cancer: possible role of a metastasis predictor. Eur J Cancer 2003, 39, 184-91.

51. Zwicker, J.I.; Liebman, H.A.; Neuberg, D.; Lacroix, R.; Bauer, K.A.; Furie, B.C.; Furie, B. Tumor-derived tissue factor-bearing microparticles are associated with venous thromboembolic events in malignancy. Clin Cancer Res 2009, 15, 6830-40.

52. Bebawy, M.; Combes, V.; Lee, E.; Jaiswal, R.; Gong, J.; Bonhoure, A.; Grau G.E. Membrane microparticles mediate transfer of P-glycoprotein to drug sensitive cancer cells. Leukemia 2009, 23, 1643-9.

53. Jorfi, S.; Ansa-Addo, E.A.; Kholia, S.; Stratton, D.; Valley, S.; Lange, S.; Inal, J. Inhibition of microvesiculation sensitizes prostate cancer cells to chemotherapy and reduces docetaxel dose required to limit tumor growth in vivo. Sci Rep 2015, 5, 13006.

54. Nakashima, K.; Hagiwara, T.; Ishigami, A.; Nagata, S.; Asaga, H.; Kuramoto, M.; Senshu, T.; Yamada, M. Molecular characterization of peptidylarginine deiminase in HL-60 cells induced by retinoic acid and 1alpha,25-dihydroxyvitamin D3. J Biol Chem 1999, 274, 27786-92.

55. Wang, L.; Chang, X.; Yuan, G.; Zhao, Y.; Wang, P. Expression of peptidylarginine deiminase type 4 in ovarian tumors. Int J Biol Sci 2010, 6, 454-64.

56. Cherrington, B.D.; Zhang, X.; McElwee, J.L.; Morency, E.; Anguish, L.J.; Coonrod, S.A. Potential role for PAD2 in gene regulation in breast cancer cells. PLoS One 2012, 7:e41242. 
57. Asaga, H.; Nakashima, K.; Senshu, T.; Ishigami, A.; Yamada, M. Immunocytochemical localization of peptidylarginine deiminase in human eosinophils and neutrophils. J Leukoc Biol 2001, 70:46-51.

58. Nakashima, K.; Hagiwara, T.; Yamada, M. Nuclear localization of peptidylarginine deiminase V and histone deimination in granulocytes. J Biol Chem 2002, 277:49562-8.

59. Mastronardi, F.G.; Wood, D.D.; Mei, J.; Raijmakers, R.; Tseveleki, V.; Dosch, H.M.; Probert, L.; CasacciaBonnefil, P.; Moscarello, M.A. Increased citrullination of histone H3 in multiple sclerosis brain and animal models of demyelination: a role for tumor necrosis factor-induced peptidylarginine deiminase 4 translocation. J Neurosci 2006, 26(44), 11387-96.

60. Li, P.; Yao, H.; Zhang, Z.; Li, M.; Luo, Y.; Thompson, P.R.; Gilmour, D.S.; Wang Y. Regulation of p53 target gene expression by peptidylarginine deiminase 4. Mol Cell Biol 2008, 28, 4745-58.

61. Tanikawa, C.; Ueda, K.; Nakagawa, H.; Yoshida, N.; Nakamura, Y.; Matsuda, K. Regulation of protein Citrullination through p53/PADI4 network in DNA damage response. Cancer Res 2009, 69, 8761-9.

62. Zhang. X.; Gamble M.J.; Stadler, S.; Cherrington, B.D.; Causey, C.P.; Thompson, P.R.; Roberson, M.S.; Kraus, W.L.; Coonrod, S.A. Genome-wide analysis reveals PADI4 cooperates with Elk-1 to activate c-Fos expression in breast cancer cells. PLoS Genet 2011, 7, e1002112.

63. Li, P.; Wang, D.; Yao, H.; Doret, P.; Hao, G.; Shen, Q.; Qiu, H.; Zhang, X.; Wang, Y.; Chen, G.; Wang, Y. Coordination of PAD4 and HDAC2 in the regulation of p53-target gene expression. Oncogene 2010, 29, 3153-62.

64. Chang, X.; Han, J. Expression of peptidylarginine deiminase type 4 (PAD4) in various tumors. Mol Carcinog 2006, 45, 183-96.

65. Yao, H.; Li, P.; Venters, B.J.; Zheng, S.; Thompson, P.R.; Pugh, B.F.; Wang, Y. Histone Arg modifications and p53 regulate the expression of OKL38, a mediator of apoptosis. J Biol Chem 2008, 283, 20060-8.

66. Guo, Q.; Fast, W. Citrullination of inhibitor of growth 4 (ING4) by peptidylarginine deminase 4 (PAD4) disrupts the interaction between ING4 and p53. J Biol Chem 2011, 286, 17069-78.

67. Wang, Y.; Wysocka, J.; Sayegh, J.; Lee, Y.H.; Perlin, J.R.; Leonelli, L.; Sonbuchner, L.S.; McDonald, C.H.; Cook, R.G.; Dou, Y.; Roeder, R.G.; Clarke, S.; Stallcup, M.R.; Allis, C.D.; Coonrod, S.A. Human PAD4 regulates histone arginine methylation levels via demethylimination. Science 2004, 306, 279-83.

68. U, K.P.; Subramanian, V.; Nicholas, A.P.; Thompson, P.R.; Ferretti, P. Modulation of calcium-induced cell death in human neural stem cells by the novel peptidylarginine deiminase-AIF pathway. Biochim Biophys Acta 2014, 1843, 1162-71.

69. Cuthbert, G.L.; Daujat, S.; Snowden, A.W.; Erdjument-Bromage, H.; Hagiwara, T.; Yamada, M.; Schneider, R.; Gregory, P.D.; Tempst, P.; Bannister, A.J.; Kouzarides, T. Histone deimination antagonizes arginine methylation. Cell 2004, 118, 545-53.

70. Zhang, X.; Bolt, M.; Guertin, M.J.; Chen, W.; Zhang, S.; Cherrington, B.D.; Slade, D.J.; Dreyton, C.J.; Subramanian, V.; Bicker, K.L.; Thompson, P.R.; Mancini, M.A.; Lis, J.T.; Coonrod, S.A. Peptidylarginine deiminase 2-catalyzed histone $\mathrm{H} 3$ arginine 26 citrullination facilitates estrogen receptor alpha target gene activation. Proc Natl Acad Sci USA 2012, 109(33), 13331-13336.

71. Kosgodage, U.S.; Trindade, R.P.; Thompson P.R.; Inal J.I.; Lange, S. Combined inhibition of Peptidylarginine Deiminase and Protein Kinase C-mediated microvesicle release significantly enhances efficacy of cancer chemotherapy. Int J Mol Sci - Special Issue: Extracellular Vesicles for Therapeutic Applications: What's the Story? (under review)

72. Fuhrmann, J.; Thompson, PR. Protein Arginine Methylation and Citrullination in Epigenetic Regulation. ASC Chem Biol 2015, 11(3), 654-68.

73. Salzer, U.; Hinterdorfer, P.; Hunger, U.; Borken, C.; Prohaska, R. Ca(++)-dependent vesicle release from erythrocytes involves stomatin-specific lipid rafts, synexin (annexin VII), and sorcin. Blood 2002, 99, 256977.

74. Pizzirani, C.; Ferrari, D.; Chiozzi, P.; Adinolfi, E.; Sandonà, D.; Savaglio, E.; Di Virgilio, F. Stimulation of P2 receptors causes release of IL-1beta-loaded microvesicles from human dendritic cells. Blood 2007, 109, 385664.

75. Lemoinne, S.; Thabut, D.; Housset, C.; Moreau, R.; Valla, D.; Boulanger, C.M.; Rautou, P.E. The emerging roles of microvesicles in liver diseases. Nat Rev Gastroenterol Hepatol 2014, 11, 350-61.

76. Coleman, M.L.; Sahai, E.A.; Yeo, M.; Bosch, M.; Dewar, A.; Olson, M.F. Membrane blebbing during apoptosis results from caspase-mediated activation of ROCK I. Nat Cell Biol 2001, 3, 339-45. 
77. Bunnell, T.M.; Burbach, B.J.; Shimizu, Y.; Ervasti, J.M. beta-Actin specifically controls cell growth, migration, and the G-actin pool. Mol Biol Cell 2011, 22, 4047-4058.

78. van Beers, J.J.; Schwarte, C.M.; Stammen-Vogelzangs, J.; Oosterink, E.; Božič, B.; Pruijn, G.J. The rheumatoid arthritis synovial fluid citrullinome reveals novel citrullinated epitopes in apolipoprotein E, myeloid nuclear differentiation antigen, and beta-actin. Arthritis Rheum 2013, 65, 69-80.

79. van Beers, J.J.B.V.; Pruijn, G.J.M. The Role of Synovial Citrullinated Proteins in the Pathophysiology of Rheumatoid Arthritis. In: Nicholas, A.P.; Bhattacharya, S.K., Eds. Protein deimination in human health and disease. New York, NY: Springer Science and Business Media 2014, Chapter 3.

80. Darrah, E.; Rosen, A.; Giles, J.T.; Andrade, F. Peptidylarginine deiminase 2, 3 and 4 have distinct specificities against cellular substrates: novel insights into autoantigen selection in rheumatoid arthritis. Ann Rheum Dis 2012, 71(1), 92-98.

81. Knuckley, B.; Luo, Y.; Thompson, P.R. Profiling Protein Arginine Deiminase 4 (PAD4): a novel screen to identify PAD4 inhibitors. Bioorg Med Chem 2008, 16, 739-45.

82. Slack, J.L.; Causey, C.P.; Thompson, P.R. Protein arginine deiminase 4: a target for an epigenetic cancer therapy. Cell Mol Life Sci 2011, 68, 709-20.

83. Pritzker, L.B.; Moscarello, M.A. A novel microtubule independent effect of paclitaxel: the inhibition of peptidylarginine deiminase from bovine brain. Biochim Biophys Acta 1998, 1388(1), 154-60.

84. Tarcsa, E.; Marekov, L.N.; Mei, G.; Melino, G.; Lee, S.C.; Steinert, P.M. Protein unfolding by peptidylarginine deiminase. Substrate specificity and structural relationships of the natural substrates trichohyalin and filaggrin. J Biol Chem 1996, 271, 30709-16.

85. Knuckley, B.; Causey, C.P.; Jones, J.E.; Bhatia, M.; Dreyton, C.J.; Osborne, T.C.; Takahara, H.; Thompson, P.R. Substrate specificity and kinetic studies of PADs 1,3, and 4 identify potent and selective inhibitors of protein arginine deiminase 3. Biochemistry 2010, 49, 4852-63.

86. Assohou-Luty, C.; Raijmakers, R.; Benckhuijsen, W.E; Stammen-Vogelzangs, J.; de Ru, A.; van Veelen, PA.; Franken, K.L.; Drijfhout, J.W.; Pruijn, G.J. The human peptidylarginine deiminases type 2 and type 4 have distinct substrate specificities. Biochim Biophys Acta 2014, 1844(4), 829-36.

87. Arita, K.; Hashimoto, H.; Shimizu, T.; Nakashima, K.; Yamada, M.; Sato, M. Structural basis for Ca(2+)induced activation of human PAD4. Nat Struct Mol Biol 2004, 11(8), 777-783.

88. Anzilotti, C.; Merlini, G.; Pratesi, F.; Tommasi, C.; Chimenti, D.; Migliorini, P. Antibodies to viral citrullinated peptide in rheumatoid arthritis. J Rheumatol 2006, 33, 647-51.

89. Yoshida M.; Tsuji M.; Kurosaka, D.; Kurosaka, D.; Yasuda, J.; Ito, Y.; Nishizawa, T.; Yamada, A. Autoimmunity to citrullinated type II collagen in rheumatoid arthritis. Mod Rheumatol 2006, 16(5), $276-281$.

90. Zhao, X.; Okeke N.L.; Sharpe, O.; Batliwalla, F.M.; Lee, A.T.; Ho, P.P.; Tomooka, B.H.; Gregersen, P.K.; Robinson, W.H. Circulating immune complexes contain citrullinated fibrinogen in rheumatoid arthritis. Arthritis Res Ther 2008, 10(4), R94.

91. Jones, J.E.; Causey, C.P.; Knuckley, B.; Slack-Noyes, J.L.; Thompson, P.R. Protein arginine deiminase 4 (PAD4): current understanding and future therapeutic potential. Curr Opin Drug Discov Devel 2009, 12(5), 616-627.

92. Dwivedi, N.; Upadhyay, J.; Neeli, I.; Khan, S.; Pattanaik, D.; Myers, L.; Kirou, K.A.; Hellmich, B.; Knuckley, B.; Thompson, P.R.; Crow, M.K.; Mikuls, T.R.; Csernok, E.; Radic, M. Felty's syndrome autoantibodies bind to deiminated histones and neutrophil extracellular traps. Arthritis Rheum 2012, 64(4), 982-992.

93. Cherian, P.; Hankey, G.J.; Eikelboom, J.W.; Thom, J.; Baker, R.I.; McQuillan, A.; Staton, J.; Yi, Q. Endothelial and platelet activation in acute ischemic stroke and its etiological subtypes. Stroke 2003, 34(9), $2132-7$.

94. Simak J.; Gelderman M.P.; Yu H.; Wright, V.; Baird, A.E. Circulating endothelial microparticles in acute ischemic stroke: a link to severity, lesion volume and outcome. J Thromb Haemost 2006, 6, 1296-302.

95. Lazarus, R.C.; Buonora, J.E.; Flora, M.N.; Freedy, J.G.; Holstein, G.R.; Martinelli, G.P.; Jacobowitz, D.M.; Mueller, G.P. Protein Citrullination: A Proposed Mechanism for Pathology in Traumatic Brain Injury. Front Neurol 2015, 6, 204.

96. Tomlinson, P.R.; Zheng, Y.; Fischer, R.; Heidasch, R.; Gardiner, C.; Evetts, S.; Hu, M.; Wade-Martins, R.; Turner, M.R.; Morris, J.; Talbot, K.; Kessler, B.M.; Tofaris, G.K. Identification of distinct circulating exosomes in Parkinson's disease. Ann Clin Transl Neurol 2015, 2(4), 353-61.

97. Agosta, F.; Dalla Libera, D; Spinelli, E.G.; Finardi, A.; Canu, E.; Bergami, A.; Bocchio Chiavetto, L.; Baronio, M.; Comi, G.; Martino, G.; Matteoli, M.; Magnani, G.; Verderio, C.; Furlan, R. Myeloid microvesicles in 
cerebrospinal fluid are associated with myelin damage and neuronal loss in mild cognitive impairment and Alzheimer disease. Ann Neurol 2014, 76(6), 813-25.

98. Burgos, K.; Malenica, I.; Metpally, R. Courtright, A.; Rakela, B.; Beach, T.; Shill, H.; Adler, C.; Sabbagh, M.; Villa, S.; Tembe, W.; Craig, D.; Van Keuren-Jensen, K. Profiles of extracellular miRNA in cerebrospinal fluid and serum from patients with Alzheimer's and Parkinson's diseases correlate with disease status and features of pathology. PLoS One 2014, 9(5), e94839.

99. Joshi, P.; Turola, E.; Ruiz, A.; Bergami, A.; Libera, D.D.; Benussi, L.; Giussani, P.; Magnani, G.; Comi, G.; Legname, G.; Ghidoni, R.; Furlan, R.; Matteoli, M.; Verderio, C. Microglia convert aggregated amyloid- $\beta$ into neurotoxic forms through the shedding of microvesicles. Cell Death Differ 2014, 21(4), 582-93.

100. Frühbeis, C.; Fröhlich, D.; Kuo, W.P.; Amphornrat, J.; Thilemann, S.; Saab, A.S.; Kirchhoff, F.; Möbius, W.; Goebbels, S.; Nave, K.A.; Schneider, A.; Simons, M.; Klugmann, M.; Trotter, J.; Krämer-Albers, E.M. Neurotransmitter-triggered transfer of exosomes mediates oligodendrocyte-neuron communication. PLoS Biol 2013, 11, e1001604.

101. Basso, M.; Pozzi S.; Tortarolo, M.; Fiordaliso, F.; Bisighini, C.; Pasetto, L.; Spaltro, G.; Lidonnici, D.; Gensano, F.; Battaglia, E.; Bendotti, C.; Bonetto, V. Mutant copper-zinc superoxide dismutase (SOD1) induces protein secretion pathway alterations and exosome release in astrocytes: implications for disease spreading and motor neuron pathology in amyotrophic lateral sclerosis. J Biol Chem 2013, 288(22), 1569915711.

102. Grad, L.I.; Yerbury, J.J.; Turner, B.J.; Guest, W.C.; Pokrishevsky, E.; O'Neill, M.A.; Yanai, A.; Silverman, J.M.; Zeineddine, R.; Corcoran, L.; Kumita, J.R.; Luheshi, L.M.; Yousefi, M.; Coleman, B.M.; Hill, A.F.; Plotkin, S.S.; Mackenzie, I.R.; Cashman, N.R. Intercellular propagated misfolding of wild-type $\mathrm{Cu} / \mathrm{Zn}$ superoxide dismutase occurs via exosome-dependent and -independent mechanisms. Proc Natl Acad Sci USA 2014, 111(9), 3620-5.

103. Feneberg, E.; Steinacker, P.; Lehnert, S.; Schneider, A.; Walther, P.; Thal, D.R.; Linsenmeier, M.; Ludolph, A.C.; Otto, M. Limited role of free TDP-43 as a diagnostic tool in neurodegenerative diseases. Amyotroph Lateral Scler Frontotemporal Degener 2014, 15(5-6), 351-6.

104. Eitan, C.; Hornstein, E. Vulnerability of microRNA biogenesis in FTD-ALS. Brain Res 2016, 15, 1647, 105-11.

105. Gascon, E.; Gao, F.B. The emerging roles of microRNAs in the pathogenesis of frontotemporal dementiaamyotrophic lateral sclerosis (FTD-ALS) spectrum disorders. J Neurogenet 2014, 28(1-2), 30-40.

106. Saman, S.; Kim, W.; Raya, M.; Visnick, Y.; Miro, S.; Saman, S.; Jackson, B.; McKee, A.C.; Alvarez, V.E.; Lee, N.C., Hall, G.F.. Exosome-associated tau is secreted in tauopathy models and is selectively phosphorylated in cerebrospinal fluid in early Alzheimer disease. J Biol Chem 2012, 287, 3842-3849.

107. Bellingham, S.A.; Guo, B.; Hill, A.F. The secret life of extracellular vesicles in metal homeostasis and neurodegeneration. Biol Cell 2015, 107(11), 389-418.

108. Danzer, K.M.; Kranich, L.R.; Ruf, W.P.; Cagsal-Getkin, O.; Winslow, A.R.; Zhu, L.; Vanderburg, C.R.; McLean, P.J. Exosomal cell-to-cell transmission of alpha synuclein oligomers. Mol Neurodegener 2012, 7, 42.

109. Fraser, K.B.; Moehle, M.S.; Daher, J.P.; Webber, P.J.; Williams, J.Y.; Stewart, C.A.; Yacoubian, T.A.; Cowell, R.M.; Dokland, T.; Ye T.; Chen, D.; Siegal, G.P.; Galemmo, R.A.; Tsika, E.; Moore, D.J.; Standaert, D.G.; Kojima, K.; Mobley, J.A.; West, A.B. LRRK2 secretion in exosomes is regulated by 14-3-3. (2013). Hum Mol Genet 2013, 22(24), 4988-5000.

110. Chang, C.; Lang, H.; Gen, N.; Wang, J.; Li, N.; Wang, X. Exosomes of BV-2 cells induced by alpha-synuclein: important mediator of neurodegeneration in PD. Neurosci Lett 2013, 548, 190-195.

111. Rajendran, L.; Honsho, M.; Zahn, T.R.; Keller, P.; Geiger, K.D.; Verkade. P.; Simons, K. Alzheimer's disease $\beta$-amyloid peptides are released in association with exosomes. Proc Natl Acad Sci USA 2006, 103(30), 1117211177.

112. Eitan, E.; Hutchison, E.R.; Marosi, K.; Comotto, J.; Mustapic, M.; Nigam, S.M.; Suire, C.; Maharana, C.; Jicha, G.A.; Liu, D.; Machairaki, V.; Witwer, K.W.; Kapogiannis, D.; Mattson, M.P. Extracellular VesicleAssociated A $\beta$ Mediates Trans-Neuronal Bioenergetic and Ca2+-Handling Deficits in Alzheimer's Disease Models. NPJ Aging Mech Dis 2016, 2 pii: 16019.

113. Jucker, M.; Walker, L.C. Self-propagation of pathogenic protein aggregates in neurodegenerative diseases. Nature 2013, 501(7465), 45-51.

114. Polanco, J.C.; Scicluna, B.J.; Hill, A.F.; Götz, J. Extracellular vesicles isolated from brains of rTg4510 mice seed tau aggregation in a threshold-dependent manner. J Biol Chem 2016, 291(24), 12445-66. 
115. Fevrier, B.; Vilette, D.; Archer, F.; Loew, D.; Faigle, W.; Vidal, M.; Laude, H.; Raposo, G. Cells release prions in association with exosomes. Proc Natl Acad Sci USA 2004, 101, 9683-9688.

116. Leblanc, P.; Alais, S.; Porto-Carreiro, I.; Lehmann, S.; Grassi, J.; Raposo, G.; Darlix, J.L. Retrovirus infection strongly enhances scrapie infectivity release in cell culture. EMBO J 2006, 25(12):2674-85.

117. Vella, L.J.; Sharples, R.A.; Lawson, V.A.; Masters, C.L.; Cappai, R., Hill, A.F. Packaging of prions into exosomes is associated with a novel pathway of PrP processing. J Pathol 2007, 211(5), 582-590.

118. Alais, S.; Simoes, S.; Baas, D.; Lehmann, S.; Raposo, G.; Darlix, J.L.; Leblanc, P. Mouse neuroblastoma cells release prion infectivity associated with exosomal vesicles. Biol Cell 2008, 100(10), 603-615.

119. Mattei, V.; Barenco, M.G.; Tasciotti, V.; Garofalo, T.; Longo, A.; Boller, K.; Lower, J.; Misasi, R.; Montrasio, F.; Sorice, M. Paracrine diffusion of $\operatorname{PrP}(\mathrm{C})$ and propagation of prion infectivity by plasma membranederived microvesicles. PLoS One 2009, 4, e5057.

120. Hosseinzadeh, S.; Zahmatkesh, M.; Zarrindast, M.R.; Hassanzadeh, G.R.; Karimian, M.; Sarrafnejad, A. Elevated CSF and plasma microparticles in a rat model of streptozotocin-induced cognitive impairment. Behav Brain Res 2013, 256, 503-511.

121. Fillit, H.; Ding, WH.; Buee, L.; Kalman, J.; Altstiel, L.; Lawlor, B.; Wolf-Klein, G. Elevated circulating tumor necrosis factor levels in Alzheimer's disease. Neurosci Lett 1991, 129(2), 318-320.

122. Prokop, S.; Miller, K.R.; Heppner, F.L. Microglia actions in Alzheimer's disease. Acta Neuropathol 2013, 126(4), 461-477.

123. Heppner, F.L.; Ransohoff, R.M.; Becher, B. Immune attack: the role of inflammation in Alzhheimer disease. Nat Rev Neurosci 2015, 16(6), 358-72.

124. Zenaro, E.; Pietronigro, E.; Bianca, V.D.; Piacentino, G.; Marongiu, L.; Budui, S.; Turano, E.; Rossi, B.; Angiari, S.; Dusi, S.; Motresor, A.; Carlucci,T.; Nani, S.; Tosador, G.; Calciano, L.; Catalucci, D.; Berton, G.; Bonetti, B.; Constantin, G. Neutrophils promote Alzheimer's disease-like pathology and cognitive decline via LFA-1 integrin. Nat Med 2015, 21(8), 880-886.

125. Eyre, J.; Burton, J.O.; Saleem, M.A.; Mathieson, P.W.; Topham, P.S.; Brunskill, N.J. Monocyte- and endothelial-derived microparticles induce an inflammatory phenotype in human podocytes. Nephron Exp Nephrol 2011, 119(3), e58-66.

126. Moscarello, M.A.; Wood, D.D.; Ackerley, C.; Boulias, C. Myelin in multiple sclerosis is developmentally immature. J Clin Invest 1994, 94 (1), 146-54.

127. Musse, A.A.; Li, Z.; Ackerley, C.A.; Bienzle, D.; Lei, H.; Poma, R.; Harauz, G.; Moscarello, M.A.; Mastronardi, F.G. Peptidylarginine deiminase 2 (PAD2) overexpression in transgenic mice leads to myelin loss in the central nervous system. Dis Model Mech 2008, 1(4-5), 229-40.

128. Wood D.D.; Ackerley C.A.; Brand, B.; Zhang, L.; Raijmakers, R.; Mastronardi, F.G.; Moscarello M.A. Myelin localization of peptidylarginine deiminases 2 and 4: comparison of PAD2 and PAD4 activities. Lab Invest 2008, 88(4), 354-64.

129. Bradford, C.M.; Ramos I.; Cross, A.K.; Haddock, G.; McQuaid, S.; Nicholas, A.P.; Woodroofe, M.N. Localisation of citrullinated proteins in normal appearing white matter and lesions in the central nervous system in multiple sclerosis. J Neuroimmunol 2014, 273(1-2), 85-95.

130. Nicholas, A.P.; King, J.L.; Sambandam, T.; Echols, J.D.; Gupta, K.B.; McInnis, C.; Whitaker, J.N. Immunohistochemical localization of citrullinated proteins in adult rat brain. J Comp Neurol 2003, 459, 251266.

131. Nicholas, A.P.; Sambandam, T.; Echols, J.D.; Tourtellotte, W.W. Increased citrullinated glial fibrillary acidic protein in secondary progressive multiple sclerosis. J Comp Neurol 2004, 473, 128-136.

132. Nicholas, A.P.; Sambandam, T.; Echols, J.D.; Barnum, S.R. Expression of citrullinated proteins in murine experimental autoimmune encephalomyelitis. J Comp Neurol 2005, 486, $254-266$.

133. Borchelt, D.R.; Thinakaran, G.; Eckman, C.B.; Lee, M.K.; Davenport, F.; Ratovitsky, T.; Prada, C.M.; Kim, G.; Seekins, S.; Yager, D.; Slunt, HH.; Wang, R.; Seeger, M.; Levey, AI.; Gandy, SE.; Copeland, NG.; Jenkins, NA.; Price, DL.; Younkin, SG.; Sisodia, S.S. Familial Alzheimer's disease-linked presenilin 1 variants elevate Abeta1-42/1-40 ratio in vitro and in vivo. Neuron 1996, 17(5), 1005-13.

134. Ishigami, A.; Masutomi, H.; Handa, S.; Nakamura, M.; Nakaya, S.; Uchida, Y.; Saito, Y.; Murayama, S.; Jang, B.; Jeon, Y.C.; Choi, E.K.; Kim, Y.S.; Kasahara, Y.; Maruyama, N.; Toda T. Mass spectrometric identification of citrullination sites and immunohistochemical detection of citrullinated glial fibrillary acidic protein in Alzheimer's disease brains. J Neurosci Res 2015, 93(11), 1664-74. 
135. Mohlake, P.; Whiteley, C.G. Arginine metabolising enzymes as therapeutic tools for Alzheimer's disease: peptidyl arginine deiminase catalyses fibrillogenesis of beta-amyloid peptides. Mol Neurobiol 2010, 41(2-3), 149-58.

136. Jang, B.; Jeon, Y.C.; Choi, J.K.; Park, M.; Kim, J.I.; Ishigami, A.; Maruyama, N.; Carp, R.I.; Kim, Y.S.; Choi, E.K. Peptidylarginine deiminase modulates the physiological roles of enolase via citrullination: links between altered multifunction of enolase and neurodegenerative diseases. Biochem J 2012, 445(2), 183-92.

137. Acharya,N.K.; Nagele, E.P.; Han, M.; Coretti, N.J.; DeMarshall, C.; Kosciuk, M.C.; Boulos, P.A.; Nagele, R.G. Neuronal PAD4 expression and protein citrullination: possible role in production of autoantibodies associated with neurodegenerative disease. J Autoimmun 2012, 38 (4), 369-80.

138. Nagele, R.G.; Clifford, P.M.; Siu, G.; Levin, E.C.; Acharya, N.K.; Han, M.; Kosciuk, M.C.; Venkataraman, V.; Zavareh, S.; Zarrabi, S.; Kinsler, K.; Thaker, N.G.; Nagele, E.P.; Dash, J.; Wang, H.Y.; Levitas, A. Brainreactive autoantibodies prevalent in human sera increase intraneuronal amyloid-beta1-42 deposition. J Alzheimers Dis 2011, 25:605e22.

139. Gross, J.C.; Chaudhary, V.; Bartscherer, K.; Boutros, M. Active Wnt proteins are secreted on exosomes. Nat Cell Biol 2012, 14(10), 1036-45.

140. Yang, Y.; Kim, J.; Kim, H.Y.; Ryoo, N.; Lee, S.; Kim, Y.; Rhim, H.; Shin, Y.K. Amyloid- $\beta$ Oligomers May Impair SNARE-Mediated Exocytosis by Direct Binding to Syntaxin 1a. Cell Rep 2015, 12(8):1244-51.

141. Luo, Y.; Knuckley, B.; Lee, Y.H.; Stallcup, M.R.; Thompson, P.R. A fluoroacetamidine-based inactivator of protein arginine deiminase 4: design, synthesis, and in vitro and in vivo evaluation. J Am Chem Soc 2006, 128, 1092-3.

142. Bozdag, M.; Dreker, T.; Henry, C.; Tosco, P.; Vallaro, M.; Fruttero, R.; Scozzafava, A.; Carta, F.; Supuran, C.T. Novel small molecule protein arginine deiminase 4 (PAD4) inhibitors. Bioorg Med Chem Lett 2013, 23(3), 715-9.

143. Ferretti, P.; U, K.P.; Vagaska, B.; Merchant, R.; Matthews, C.J.; Marson, C.M. Discovery of a structurally novel, drug-like and potent inhibitor of peptidylarginine deiminase. Med Chem Commun 2013, 4, 1109-1113.

144. Wei, L.; Wasilewski, E.; Chakka, S.K.; Bello, A.M.; Moscarello, M.A.; Kotra, L.P. Novel inhibitors of protein arginine deiminase with potential activity in multiple sclerosis animal model. J Med Chem 2013, 56(4), 171522.

145. Subramanian, V.; Knight, J.S.; Parelkar, S.; Anguish, L.; Coonrod, S.A.; Kaplan, M.J.; Thompson, P.R. Design, synthesis, and biological evaluation of tetrazole analogs of $\mathrm{Cl}$-amidine as protein arginine deiminase inhibitors. J Med Chem 2015, 58(3), 1337-44.

146. Trabocchi, A.; Pala, N.; Krimmelbein, I.; Menchi, G.; Guarna, A.; Sechi, M.; Dreker, T.; Scozzafava, A.; Supuran, C.T.; Carta, F. Peptidomimetics as protein arginine deiminase 4 (PAD4) inhibitors. J Enzyme Inhib Med Chem 2015, 30(3), 466-71.

(C) 2017 by the authors. Licensee Preprints, Basel, Switzerland. This article is an open access article distributed under the terms and conditions of the Creative Commons by Attribution (CC-BY) license (http://creativecommons.org/licenses/by/4.0/). 